\title{
Exploring the Moderating Role of Lean Production on Supplier Performance: An Empirical Study of Turkish Automotive Part Suppliers
}

\author{
İbrahim S. Karakadılar* \\ Nişantaşı University
}

\author{
Ben J. Hicks** \\ University of Bristol
}

\begin{abstract}
The aim of this study is to investigate the effect of strategic partnership, information technology and lean production techniques on the operational performance of Turkish automotive part suppliers by conducting a Structural Equation Modelling (SEM) path analysis. Survey data was gathered from 207 automotive part suppliers in Turkey. It was observed that internal lean production techniques implementation level and information technology tools had a positive effect on a supplier's operational performance, whereas no significant statistical relationship was found between strategic partnership and operational performance, except for the condition where the moderating effect of internal lean production techniques was involved. Consequently, this research verifies the importance and benefits of implementing lean production techniques for supplier firms.
\end{abstract}

Keywords: lean production, supply chain integration, SPSS-AMOS.

\section{Yalın Üretim Tekniklerinin Tedarikçi Performansını Biçimleyici Etkisinin Araştırılması: Türkiye'deki Otomotiv Tedarikçileri Üzerine Nicel Bir Çalışma}

\section{Özet}

Bu çalışmanın amacı stratejik ortaklık, bilgi teknolojileri ve yalın üretim tekniklerinin tedarikçilerin performansı üzerindeki etkilerini yapısal eşitlik modeli (YEM) analizi ile araştırmaktır. Araştırma verileri Türkiye'deki 207 otomotiv tedarikçisi firmadan temin edilmiştir. Yalın üretim tekniklerinin uygulanmasının ve bilgi teknolojisi araçlarından faydalanılmasının tedarikçinin operasyonel performansına olumlu etkisi olduğu, stratejik ortaklık ile operasyonel performans arasındaki ilişkide ise yalın üretim uygulamaların biçimleyici etkisi dışında istatistiksel olarak anlamlı bir ilişki bulunmadığı ortaya konmuştur. Sonuç olarak, bu araştırma yalın üretim tekniklerinin uygulanmasının tedarikçi firmalara sağladığı faydaları ve söz konusu tekniklerin önemini ortaya koymaktadır.

Anahtar kelimeler: yalın üretim, tedarik zinciri entegrasyonu, SPSS-AMOS.

* İbrahim S. Karakadılar is an Assistant Professor in the Department of International Trade and Logistics at Nişantaş1 University, Sadabad Campus, Kağıthane, 34406, Istanbul, Turkey. E-mail: ibrahimsarper.karakadilar@nisantasi.edu.tr

** Ben J. Hicks is a Professor in the Department of Mechanical Engineering at the University of Bristol, Clifton, BS8 1TR, Bristol, United Kingdom. E-mail: ben.hicks@bristol.ac.uk 
$\mathrm{M}$ any manufacturing companies have begun to pursue a strategy of working closely with only a small number of suppliers in order to gain additional competitive advantage (Shin et al., 2000; Prahanski and Benton, 2004). A prerequisite for such close working is the effective utilisation of information and communication technologies in combination with face-to-face collaboration (Simatupang and Sridharan, 2005). Furthermore, in establishing successful close partnerships it has been suggested that a prior adoption of lean production techniques can be advantageous (Fynes et al., 2005). However, while beneficial, lean production techniques do not by themselves optimize the value for the end customer; rather, it is necessary to integrate the full spectrum of business processes to achieve this (Jayaram et al., 2008). Given the previously reported findings, it can be hypothesised that manufacturers who adopt a lean production approach are better placed to integrate their production processes with their suppliers and thus realise maximum advantage. Likewise, in order to provide this integration they should employ both information technology tools as an enabler (Prajogo and Olhager, 2012; Feng et al., 2013) and engage in strategic partnership to integrate their production processes (Krafcik, 1988; Womack et al., 1991). More general evidence in support of this hypothesised positive interaction is the acknowledged contribution of lean production approaches and close collaborative supplier relationships to the efficient output performance of the Toyota Motor Company (Womack et al., 1991).

While the individual direct effects of the aforementioned three factors (strategic supplier partnership, information technology and lean production techniques) on operational performance have been widely investigated in the existing literature (e.g. Li et al., 2005; Shah and Ward, 2007; Olhager and Prajogo, 2012; Bortolotti et al., 2013), only a small number of empirical studies acknowledge or consider the conjoint positive effect. These studies include those by Arkader (2001), Simpson and Power (2005), Jayaram et al., (2008) and Moyano-Fuentes et al., (2012). However, they are limited in a number of ways including very small sample sizes (e.g. Arkader, 2001) and consideration of only two of the factors. Moreover, within contemporary literature from the fields of supplier integration (e.g. Cousins and Menguc, 2006; Swink et al., 2007; Cao et al., 2010) and information integration (e.g. Riezebos et al., 2009; Moyano-Fuentes et al., 2012; Prajogo and Olhager, 2012) there is some empirical confusion/conflation of multiple moderating factors. There is thus a need to consider more rigorously the interdependence of the key antecedents identified in the literature including lean production techniques implementation and strategic partnerships.

In addition to the above, none of the previous studies consider the Turkish automotive industry. To support the strategic development of the Turkish automotive industry there is a requirement to confirm the existence of the relationship implied within the Toyota philosophy and to examine its strength. In this manner, future commercial decisions concerning investment in both lean production principles and supplier relationships can be better informed. Hence, this paper deals with the suppliers in the Turkish automotive industry related to buyer-supplier relations under lean production practices. Furthermore, this study employs large scale data collection $(>200)$ which enables the moderating effects of lean production techniques implementation on the 
supplier's operational performance and the relationships between strategic partnership and information technology to be tested.

In terms of the wider research findings, the study reported in this paper provides a more general insight about Turkish automotive industry in two areas. The first addresses the concerns of Turkish automotive industry managers and, in particular, the lean maturity level of the Turkish automotive industry suppliers compared to other sector suppliers. The second more general insight concerns the importance of investment in new IT tools and their impact on operational performance.

The paper is organized as follows: In the next section the proposed research framework and the constructs are defined, and research hypotheses are presented. In the methodology section, research sampling and measurement approaches are described. The data analysis and results are then presented. The final section discusses the key findings and provides future research directions.

\section{Proposed Research Framework}

The theoretical framework of this study contains two antecedent factors of the supplier's operational performance which are named as supply chain integration and lean production. In academic literature the concept of supply chain integration is generally considered across a broad perspective such as "supplier, internal and customer" integration contexts (e.g. Rosenzweig et al., 2003; Villena et al., 2009) and alludes to the importance of strategic partnership. Additionally, lean production is defined in the literature as a bundle of practices "Just in Time - Total Quality Management - Human Resource Management" (e.g. Shah and Ward, 2007; Moyano-Fuentes et al., 2012). Because of the aim and constraints of this paper these antecedent factors are investigated in a narrower context without using all the aforementioned dimensions of the two constructs. For this reason and in the context of this study, the construct of lean production is considered to be the relative deployment of lean techniques with the exclusion of the Human Resource Management context. Supply chain integration is considered by virtue of a supplier integration dimension, meaning a long-term agreement-based strategic partnership. Finally, information technology is considered as an integrating factor and from the perspective of sharing information in a timely manner.

The research framework is shown in Figure 1 which illustrates the three key antecedents: strategic partnership, information technology as an integrating factor and deployment of lean techniques in plant, and their proposed relationship to supplier's operational performance. The proposed moderating effect of lean techniques on these relationships is also included. This moderating effect analysis is performed to determine whether a suppliers' lean technique implementation maturity level is a factor in increasing the effect of other factors on operational performance. The main purpose of the developed research model is to determine the effect of antecedent variables upon the supplier's operational performance, i.e., the substantial factor needed to gain competitive advantage. 
Figure 1

\section{Proposed Research Framework}

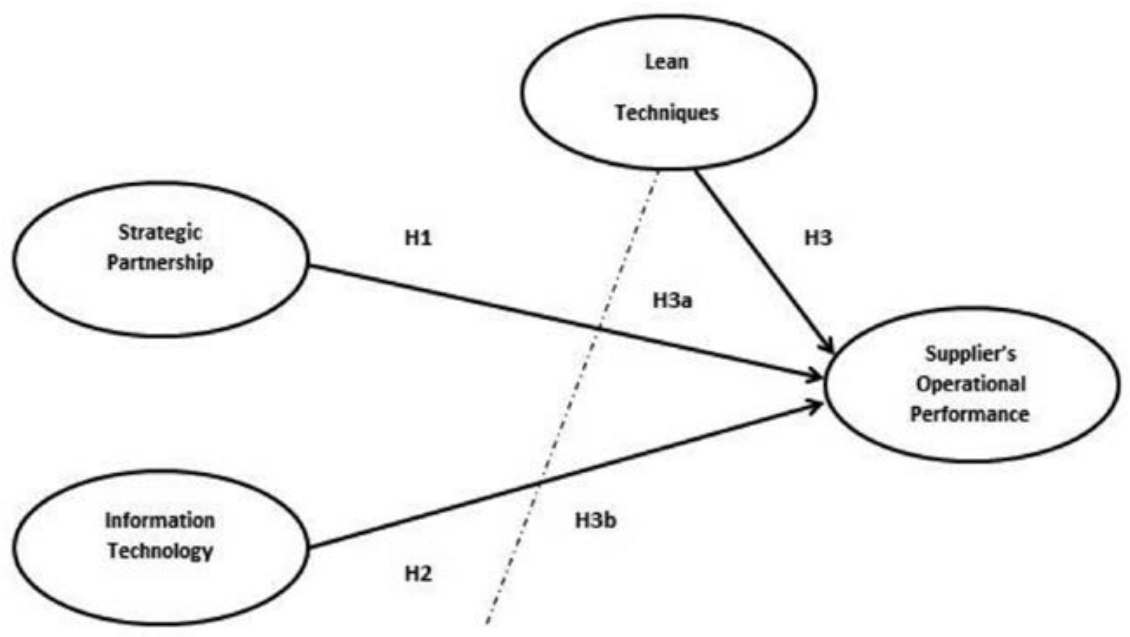

There is a general consensus in the literature that defines the competitive capabilities of supplier's operational performance as the combined price/cost of supplied commodity, product quality, delivery and flexibility (Shin et al., 2000; Chen and Paulraj, 2004; Prahinski and Benton, 2004; Paulraj et al., 2008). The price or cost criterion ${ }^{[1]}$ is generally evaluated as the most important element (Spekman et al., 1998) and is taken as a prerequisite element in selecting suppliers when measuring the supplier's competitive operational performance (Shin et al., 2000). Hence, for existing supplier relationships such as those considered in this research it is not necessary to consider this factor, since existing suppliers already meet this criterion. In this context, then, to assess the operational performance, suppliers should (i) meet the customer requirements at the specified quality level, and (ii) achieve dependable delivery performance (measured as delivery time and quantity) according to customer expectations.

\section{Strategic Partnership}

Strategic partnership is defined as creating long-term business relationships in order to increase the strategic and operational competence of production companies and their suppliers (Li et al., 2005). The companies in such a business relationship work jointly to plan and execute supply chain operations (Wiengarten et al., 2010). In this approach, suppliers make specific investments in order to meet their customers' expectations for sustaining their business relationships. As such, they frequently get involved in new product development and in creating proprietary knowledge for their customers (Dyer,

[1] See, Arkader [2001: 92] to get more detailed information about how supplier firms perceive this price/cost criterion in the emerging markets. 
1996). The main characteristics of a strategic partnership can be elicited from the criteria given by Chen and Paulraj, 2004; Li et al., 2005; Li et al., 2006; and Karakadılar and Sezen, 2012, they include:

- intent of long-term partnership;

- partner companies try to be cost effective for the ultimate production process;

- partner companies provide joint effort for mutual problem solving activities;

- being fair while sharing risk and profit;

- early supplier involvement in the new product development process.

Through this partnership approach, suppliers can deliver the materials or components on time and in good condition to the customers. Hereby the ultimate product quality can be enhanced and the supply chain network can be more responsive to customer requests. For this reason, the following hypothesis for empirical testing is proposed:

H1: Strategic Partnership with the buyer positively affects the Supplier's Operational Performance.

\section{Information Technology}

One of the most important infrastructure tools of supply chain management is information technology (IT), which integrates the activities of different parties in the value chain (Akkermans et al., 2003). Using these IT tools allows companies to perform their sales and purchasing transactions (e.g. invoicing) in a rapid, accurate and transparent manner (Cook et al., 2011). The effectiveness of today's modern supply chain management can be largely attributed to IT tools such as Enterprise Resource Planning (ERP), Electronic Data Interchange (EDI), and the Internet (Akkermans et al., 2003; Hsu et al., 2008). The required information can flow between partner companies rapidly and accurately with these IT tools; thus they create a competitive advantage when compared to other supply chain networks with relatively fewer IT tools (Holweg and Pil, 2008; Paulraj et al., 2008; Gotzamani and Theodorakioglou, 2010). Important information such as product availability, inventory level and control, shipment status, new product requirements, demand forecasts and order management can be provided with appropriate IT infrastructures in real-time (Stank et al., 1999; Hsu et al., 2008; Cook et al., 2011). Thus utilizing appropriate IT tools in the supply chain network enables accurate and near real time information flow which helps to achieve competitive performance objectives such as quality, flexibility, responsiveness and dependability and reduced uncertainty (Gunasekaran and Ngai, 2004). Therefore, it is hypothesized that:

H2: Utilization of Information Technology tools positively affects the Supplier's Operational Performance. 


\section{Lean Techniques}

The lean production approach first observed at the Toyota Motor Company in the 1960's has since been implemented by the automotive industries across the globe (Krafcik, 1988; Womack et al., 1991). The lean approach aims to increase production efficiency and quality, and to reduce whole stages stock levels and all kinds of unnecessary efforts (Hicks, 2007; Haleem et al., 2012; Martínez-Jurado and Moyano-Fuentes, 2012). In this approach, materials and component suppliers should also follow the lean production principles to achieve overall system efficiency (Sezen et al., 2012). Supplier companies can create competitive capabilities (improved process, practices and product quality) by pursuing the lean production techniques such as:

- pull production system (Sakakibara et al., 1993; Koufteros et al., 1998; Panizzolo et al., 2011; Nahm et al., 2004, Shah and Ward, 2007);

- value stream mapping (Hicks and Matthews, 2010; Hodge et al., 2011);

- preventive maintenance (Sakakibara et al., 1993; Koufteros et al., 1998; Nahm et al., 2004, Shah and Ward, 2007; Hodge et al., 2011; Haleem et al., 2012);

- continuoous cleanliness and tidiness of the shop floor (Panizzolo et al., 2011);

- root cause analysis and quality circle applications (Koufteros et al., 1998; Shah and Ward, 2007; Hicks and Matthews, 2010);

- error proof activities (Panizzolo et al., 2011);

- waste elimination (Hicks, 2007; Hodge et al., 2011).

Based on this argument, a third hypothesis is proposed:

H3: Deployment of lean techniques positively affects the Supplier's Operational Performance.

\section{The Moderating Role of Lean Techniques}

As previously stated, the Toyota production system concept includes both lean manufacturing techniques and close supplier relations (Womack et al., 1991). Furthermore, as mentioned there is a positive correlation between close supplier relations and internal lean practices (Jayaram et al., 2008) because the lean philosophy purports selecting the most suitable suppliers and then establishing the strategic buyer-supplier partnership (Sezen, 2008). To realise the main goals of the lean production (i.e. elimination of waste and creation of value with limited resources), suppliers should have low-cost and low-volume manufacturing skills (Hoyt and Huq, 2000; Hicks, 2007). In addition, it is claimed that there are further benefits of applying lean principles when suppliers join product planning and problem solving activities (Theodorakioglou et al., 2006). These factors lead to the formulation of a fourth hypothesis: 
H3a: Deployment of lean techniques positively moderates the relationship between Strategic Partnership and Supplier's Operational Performance; the higher the level scope of deployment of lean techniques, the greater the effects of Strategic Partnership on Supplier's Operational Performance.

Lean production mainly focuses on intra-enterprise performance while recognizing the necessity and importance of partnerships with suppliers and customers (Gunasekaran and Ngai, 2004). In the meantime, IT tools play an important role as facilitators for the evaluation of internal manufacturing performance such a: product scheduling, employee performance, and tracing the production cost (Sakakibara et al., 1993). Lean production can be characterized as "small batch production and high product variety." The starting point of this approach is to apply the "pull production (Kanban)" system in an effective manner. For this, there is a need to use information technologies which will provide the appropriate information flow based on the real demand data (Holweg and Pil, 2008). In fact, managing the inventory is one of the main elements of the lean approach; to manage it effectively, all relevant parts of the chain members should be included in the IT-based supply chain system (Cook et al., 2011). Thus the IT system is a complementary and enabling factor for internal lean practices (Bruun and Mefford, 2004; Ward and Zhou, 2006). Through using the IT-based supply chain network, products can be presented to the market in a more responsive and flexible manner and with cost advantages (Gunasekaran et al., 2008). Due to the time-based strategic nature of lean production, IT tools and lean approach concomitantly affect the suppliers' operational performance (Li et al., 2005). Therefore, we deduce the hypothesis:

H3b: Deployment of lean techniques positively moderates the relationship between Information Technology and Supplier's Operational Performance; the higher the level scope of deployment of lean techniques, the greater the effects of Information Technology on Supplier's Operational Performance.

\section{Research Design and Methodology}

In order to investigate the proposed hypotheses, an empirical study of Turkish automotive parts suppliers has been undertaken. Figure 2 presents the overall research methodology including the development of the survey and its measures, validity of content, and the survey participants. Figure 2 also presents the data analysis and the statistical test which are reported in the next section.

\section{Pre-survey Study}

The measurement instruments of the majority of variables in this research model have been adapted from existing literature, such as strategic partnership (cf. Li et al., 2005), information technology (cf. Paulraj et al., 2008), lean techniques (cf. Sakakibara et al., 1993; Koufteros et al., 1998; Nahm et al., 2004, Shah and Ward, 2007), and supplier's operational performance (cf. Shin et al., 2000; Prahinski and Benton, 2004; Paulraj et al., 2008). 
Figure 2

\section{Summary Diagram of Research Design and Methodology}

\section{$1^{\text {st }}$ Phase: Research Method Development}

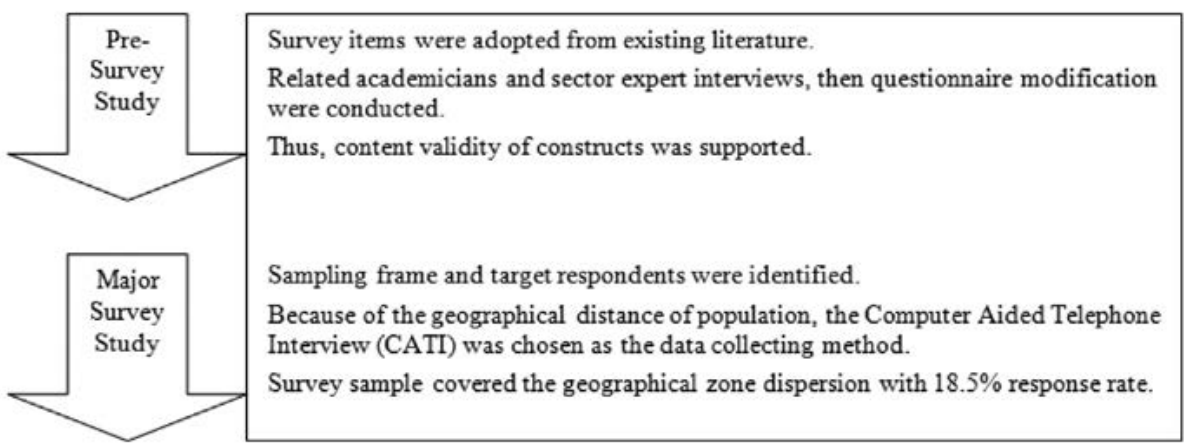

\section{$2^{\text {nd }}$ Phase: Data Analysis and Results}

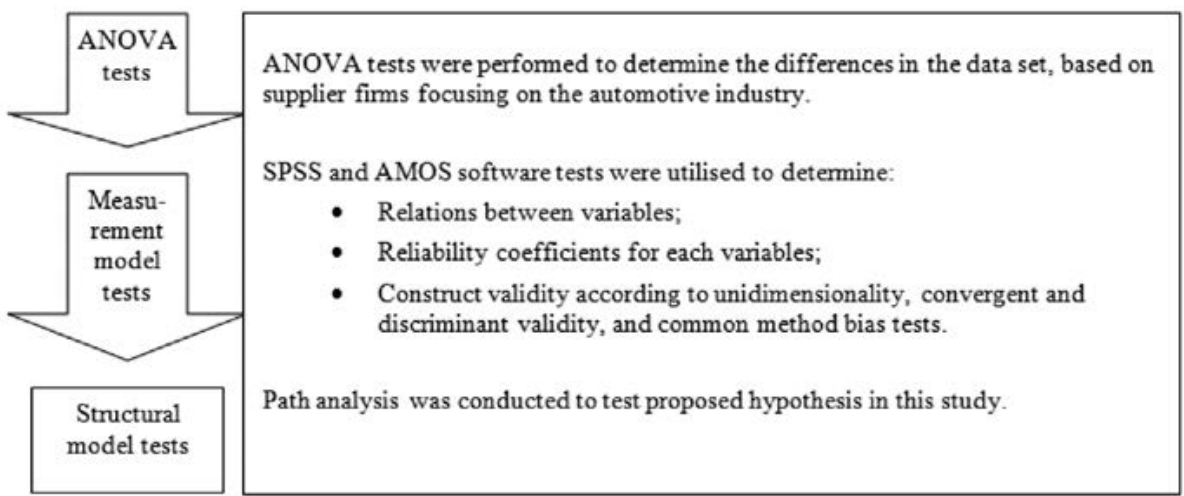

Although the measurement items are grounded in the relevant literature, their appropriateness is also checked according to a review by experts. Based on the feedback from the academics (who are experienced in supply chain management and operations management) and practitioners, ${ }^{[2]}$ redundant and ambiguous items were either modi-

[2] During that period we conducted detailed interviews with three different sector experts in order to help direct the focus of our study and to validate its content. At the beginning of the research design, an interview was done with a doyen in the industry who has worked in the sector for over 40 years. He is the owner of three different factories and a former president of the Turkish Automotive Supply Industry Association. His main focus concerned the comparison of lean maturity levels between automotive oriented suppliers versus other industries related suppliers. In particular, he felt that although Turkish supplier firms believe they implement high level lean production principles, this may not be the case when compared to other sectors. He also advocated that to enhance the Turkish automotive industry performance supplier firms should fully espouse the lean production philosophy. A second interview was undertaken with the manager of a large supplier firm. His main points concerned the overriding factor of cost reduction, and that many of their customers are unreliable when it comes to investment in joint capital/systems such as IT. He also stated 
fied or eliminated. Where necessary new items were added and the final questionnaire revision was completed. This validation of the measures provides confidence that the study is appropriately designed to measure the intended hypotheses and is similar to content validation as described by Shin et al. (2000). For each constructs' survey, items have been prepared as shown in the Appendix and responses were obtained through seven point Likert scales.

\section{Major Survey Study}

According to the structure of the proposed research framework and hypotheses the unit of analysis was decided as the suppliers' plant level dyadic relationships with their business customer manufacturer firms. The survey data was restricted to Turkish automotive parts suppliers, including suppliers to car, truck, bus, and pick-up manufacturers. This restriction was imposed because manufacturing procedures and buyer-supplier relationships of these types of vehicle producers are similar to each other based on the supplied materials. As a consequence the research sampling frame included 1,116 supplier firms from across Turkey.

Given the geographical dispersion of the Turkish suppliers, the Computer Aided Telephone Interview (CATI) method was used as the data gathering process in order to reach the survey participants easily. Hereby the collected data appropriately represented the whole sampling frame list. The survey response rate was $18.5 \%$ per cent including 207 supplier firms. This response rate is of an acceptable level, when it is compared with other studies in this field (e.g. Chen and Paulraj, 2004). According to Hair et al. (2010), over 200 observations are sufficient for the form of statistical tests undertaken in this research.

In a manner similar to other published studies concerning the buyer-supplier relationships (e.g. Chen and Paulraj, 2004; Li et al., 2006), the survey respondents were chosen from the related department managers such as operations, engineering, logistics, procurement and quality, all of whom were pre-identified as the most knowledgeable about the research topic. Table 1 shows the distribution of respondents over the four designated job roles and the composition of organizations by size.

The samples include a number of large size suppliers comparable with the small and medium sized enterprises. In order to determine whether the core business area of the participating companies is automotive or not, the share of the automotive industry within their total turnover was examined.

that decision makers often exaggerate the cost/benefit. Furthermore, the reference value (20 Million TL turnover gain from the automotive industry) by separating nonautomotive oriented suppliers was proposed and later validated by other sector experts. Finally, a third interview was carried out with the owner and CEO of a medium-sized supplier company. In this final interview we tested the points raised in the earlier interviews. In general, all points raised were verified and the interviewee added that often they do not have sufficient flexibility in their annual budget to make a high level state-of-the-art technology investment without an immediate return. 
Table 1

Sampling Profile

\begin{tabular}{|c|c|c|}
\hline Indicators & Count & Percent \\
\hline \multicolumn{3}{|c|}{ Respondents Job Title: } \\
\hline Senior executives & 40 & 20 \\
\hline Operations or engineering managers & 46 & 22 \\
\hline Logistics or procurement managers & 62 & 30 \\
\hline Quality managers & 44 & 21 \\
\hline Others & 15 & 07 \\
\hline \multicolumn{3}{|c|}{ Number of Employees: } \\
\hline Less than 50 & 66 & 32 \\
\hline $50-99$ & 34 & 16 \\
\hline $100-250$ & 54 & 26 \\
\hline More than 250 & 53 & 26 \\
\hline
\end{tabular}

$n=207$

Table 2

Automotive Industry Orientation of the Sample

\begin{tabular}{l|c|c}
\hline Indicators & Count & Percent \\
\hline \multicolumn{2}{c|}{$\begin{array}{c}\text { Annual Sales Volume in Automotive Industry (Unit Value is } \\
\text { Turkish Lira): }\end{array}$} \\
\hline Less than 19,999,999 TL & 91 & 44 \\
\hline Over 20,000,000 TL & 91 & 44 \\
\hline Missing & 25 & 12 \\
\hline
\end{tabular}

The Proportion of Automotive Industry in the Total Turnover:

\begin{tabular}{l|c|c}
\hline Less than $49 \%$ & 96 & 46 \\
\hline Over $50 \%$ & 104 & 49 \\
\hline Missing & 9 & 5 \\
\hline
\end{tabular}

$n=207$ 
As reported in Table 2, approximately $49 \%$ of the companies are mainly automotive industry oriented. On the other hand, $46 \%$ of the companies present relatively low rates with regard to their operations in the automotive industry. Examining the net revenue that companies make due to their sales to automotive industry, it is seen that almost $44 \%$ of the sample is making more than 20 million TL in an annual financial statement period (approximately $\$ 13$ million) from their auto part sales.

The descriptive results presented in Table 2 indicate that the investigated sample correctly represents the target population of the automotive parts suppliers. This is because that sampling frame contains non-automotive oriented supplier firms as much as automotive oriented supplier firms and different sized firms based on the sales volume.

\section{Data Analysis and Results}

This section initially investigates the differences in levels of lean implementation between the more automotive industry oriented suppliers and the other respondents. For this purpose, Analysis of Variance (ANOVA) tests are performed to determine differences. Then, to test the proposed hypothesis, the data set is statistically tested with a two-step approach following the guidelines suggested by Anderson and Gerbing (1988). In the first step, measurement model tests are conducted including the refinement of the survey instruments. Thus, the construct validity is proven. Then, latent variables hypothesis relations are assessed with structural model tests (Singh and Power, 2009).

\section{Analysis of Variance Tests}

To investigate the differences of implementation level, according to whether the suppliers are automotive industry oriented or not, the automotive industry oriented suppliers are defined using two criteria: (i) the turnover of the supplier from operations in the automotive industry should be over 20 million ${ }^{[3]} \mathrm{TL}$, and (ii) the proportion of automotive industry related turnover of the supplier should be over $50 \%$, as shown in Table 3. Some differences are evident, especially on the subject of implementation of internal lean practices. For instance, the Turkish suppliers' lean practices implementation levels, except the "inventory reduction and value stream mapping" items, indicate key differences between automotive industries oriented suppliers and others. Also this analysis revealed that at the buyer-supplier level, automotive industry oriented suppliers participate more in the continuous improvement programme, in the future products plan of their customers, and in utilising integrated ERP software.

\footnotetext{
[3] This reference value was determined according to interview with industry experts at the pre-survey study process.
} 
Table 3

\section{Analysis of Variance Test Results}

\begin{tabular}{|c|c|c|c|c|}
\hline \multirow{2}{*}{$\begin{array}{c}\text { Brief descriptions of measurement items } \\
\text { Strategic Partnership: }\end{array}$} & \multicolumn{2}{|c|}{$\begin{array}{c}\text { Automotive } \\
\text { Industry Turnover } \\
\text { over } \mathbf{2 0} \text { million TL } \\
\text { n=182 }\end{array}$} & \multicolumn{2}{|c|}{$\begin{array}{c}\text { Automotive } \\
\text { Industry } \\
\text { Proportion of Total } \\
\text { Turnover over } \mathbf{5 0 \%} \\
\text { n=198 }\end{array}$} \\
\hline & $\mathbf{F}$ & Sig. & $\mathbf{F}$ & Sig. \\
\hline SP1: Long-term relationship & 1.647 & 0.201 & 0.001 & 0.979 \\
\hline SP2: Participating in the continuous improvement program & 1.125 & 0.289 & 4.169 & 0.043 \\
\hline SP3: Being involved in the future plans & 0.002 & 0.964 & 0.519 & 0.472 \\
\hline SP4: Being involved in the product changing plans & 0.302 & 0.583 & 4.099 & 0.044 \\
\hline SP5: Being problem solving partner & 0.903 & 0.343 & 1.088 & 0.298 \\
\hline SP6: Intention of sustainable business relationship & 0.117 & 0.733 & 0.139 & 0.709 \\
\hline
\end{tabular}

Information Technology:

\begin{tabular}{l|l|l|l|l}
\hline IT1: Using ERP software & 2.607 & 0.108 & 5.972 & $\mathbf{0 . 0 1 5}$ \\
\hline IT2: Using cutting-edge communication technologies & 0.579 & 0.447 & 3.191 & 0.076 \\
\hline IT3: Maintaining information flow & 0.217 & 0.642 & 1.379 & 0.242 \\
\hline IT4: Rapid response for complaints and demands & 1.591 & 0.209 & 3.362 & 0.068 \\
\hline IT5: Providing inventory information flow & 0.253 & 0.615 & 0.002 & 0.965 \\
\hline
\end{tabular}

Lean Techniques:

\begin{tabular}{|c|c|c|c|c|}
\hline Lean01: Setup time reduction & 4.512 & 0.035 & 1.707 & 0.193 \\
\hline Lean02: Pull production (Kanban) & 7.305 & $\underline{0.008}$ & 5.306 & 0.022 \\
\hline Lean03: Small lot size & 6.193 & 0.014 & 8.369 & $\underline{0.004}$ \\
\hline Lean04: Inventory reduction & 1.438 & 0.232 & 2.701 & 0.102 \\
\hline Lean05: One-piece flow & 5.977 & 0.015 & 6.049 & 0.015 \\
\hline Lean06: Value stream mapping & 0.786 & 0.376 & 2.381 & 0.124 \\
\hline Lean07: Process improvement & 9.219 & $\underline{0.003}$ & 5.727 & 0.018 \\
\hline Lean08: Preventive maintenance & 5.029 & 0.026 & 3.729 & 0.055 \\
\hline Lean09: Equipment layout (cellular manufacturing) and "5S" & 22.145 & $\underline{0.000}$ & 6.168 & 0.014 \\
\hline Lean10: Order and cleanliness in the plant & 6.619 & 0.011 & 6.611 & 0.011 \\
\hline Lean11: Root cause analysis (5 Why) & 3.903 & 0.051 & 4.859 & 0.029 \\
\hline Lean12: Employee suggestion system & 8.544 & $\underline{0.004}$ & 7.135 & $\underline{0.008}$ \\
\hline Lean13: Continuous improvement (Kaizen) & 7.904 & $\underline{0.005}$ & 5.506 & 0.019 \\
\hline Lean14: Error proof equipment (Poka-Yoke) & 7.957 & $\underline{0.005}$ & 6.084 & 0.015 \\
\hline Lean15: Waste elimination & 6.008 & 0.015 & 4.726 & 0.031 \\
\hline
\end{tabular}

Note: Bold font indicates $p<0.050$, bold and underlined indicates $p<0.010$, and bold, underlined and italic indicates the strong differences at $p<0.001$ level. 


\section{Measurement Model Tests}

The measurement model tests contain three dimensions: (i) correlation and descriptive analysis, (ii) reliability and exploratory factor analysis, (iii) and confirmatory factor analysis for ensuring construct validity.

\section{Correlation Coefficients and Descriptive Statistics:}

All items for each latent variable have been grouped and transformed to composite variables based on their mean values. For each construct, mean, standard deviation, and correlation coefficients are calculated as shown in Table 4. Each construct in the research model has significant correlation relationships with others at the $p<0.01$ level and their correlation coefficient scores are less than 0.7 , indicating that there is not any potential multicollinearity problem among the observed variables in the model (Hair $e t$ al. 2010). Moreover for each constructs high mean values insure that these applications are well pursued in practice.

Table 4

Descriptive Statistics and Correlation Coefficients

\begin{tabular}{l|l|l|l|l|l|l}
\hline Constructs & Mean & SD & $\mathbf{1}$ & $\mathbf{2}$ & $\mathbf{3}$ & $\mathbf{4}$ \\
\hline 1. Strategic partnership (6 items) & 6.0717 & .86593 & - & $.423^{* *}$ & $.384^{* *}$ & $.423^{* *}$ \\
\hline 2. Information technology (5 items) & 6.0541 & .99463 & & - & $.379^{* *}$ & $.408^{* *}$ \\
\hline 3. Supplier's operational performance (5 items) & 6.4174 & .67327 & & & - & $.434^{* *}$ \\
\hline 4. Lean techniques (15 items) & 5.6783 & 1.1166 & & & & - \\
\hline
\end{tabular}

Note: $n=207 ; S D=$ Standard Deviation; ${ }^{* *}$ Correlation is significant at the 0.01 level (two-tailed)

\section{Reliability and Exploratory Factor Analysis:}

The Cronbach's alpha reliability coefficients for the four constructs -- strategic partnership, information technology, lean techniques and supplier's operational performance -- were 0.758 (for 6 items, c.f. Appendix), 0.706 (for 5 items, c.f. Appendix), 0.923 (for 15 items, c.f. Appendix) and 0.822 (for 5 items, c.f. Appendix), respectively. These coefficients suggest that the selected items reliably estimate the four constructs (Singh and Power, 2009). The inter-correlation matrix between items for each construct was utilized to determine problematic items. The results have not indicated any negative correlation between items. However some items showed low rate correlation relationships with other items of the represented constructs; as a result, these low related items (identified as SP2, IT5, and Lean4) were excluded from the data set at the beginning of the data purification process. This approach is similar to that reported by Chen and Paulraj (2004) who reduced items that methodological way; also "principal component analysis" and "method of varimax rotation with Kaiser Normalisation" were used to clarify the factors. In this item reduction process, some other items have not loaded into their factor groups and these items (SP1 and Lean3) have been excluded from the data set for remaining analyses (Chen and Paulraj, 2004). 
Table 5

Exploratory Factor Analysis Loadings after the Data Purification Process

\begin{tabular}{|c|c|c|c|c|}
\hline Measurement items & SP & IT & SOP & Lean \\
\hline \multicolumn{5}{|c|}{ Strategic Partnership: } \\
\hline SP 4: Being involved in the product changing plans & .680 & & & \\
\hline SP 5: Being problem solving partner & .825 & & & \\
\hline SP 6: Intention of sustainable business relationship & .805 & & & \\
\hline \multicolumn{5}{|l|}{ Information Technology: } \\
\hline IT 1: Using ERP software & & .704 & & \\
\hline IT 2: Using cutting-edge communication technologies & & .863 & & \\
\hline IT 3: Maintaining information flow & & .829 & & \\
\hline
\end{tabular}

Supplier's Operational Performance:

\begin{tabular}{l|l|l|l|l}
\hline SOP 1: Product quality & & & .732 & \\
\hline SOP 2: Delivery term & & & .789 & \\
\hline SOP 3: Delivery reliability & & & .828 & \\
\hline
\end{tabular}

Lean Techniques:

\begin{tabular}{l|l|l|c|c}
\hline Lean02: Pull production (Kanban) & & & & .650 \\
\hline Lean05: One-piece flow & & & & .687 \\
\hline Lean07: Process improvement & & & & .754 \\
\hline Lean08: Preventive maintenance & & & & .677 \\
\hline Lean09: Equipment layout (cellular manufacturing) and "5S" & & & & .804 \\
\hline Lean10: Order and cleanliness in the plant & & & & .808 \\
\hline Lean11: Root cause analysis (5 Why) & & & & .749 \\
\hline Lean12: Employee suggestion system & & & & .600 \\
\hline Lean14: Error proof equipment (Poka-Yoke) & & & & .766 \\
\hline
\end{tabular}

Total Variance Explained $=62,193$

Note: Extraction method principal component analysis and rotation method of varimax rotation with Kaiser Normalisation

\section{Construct Validity:}

To give evidence of the construct validity of the research framework, the confirmatory factor analysis approach was used through SPSS-AMOS. In this stage whether the variables are fulfilling the unidimensionality, convergent and discriminant validity requirements are investigated (Corsten and Felde, 2005).

The requirements for establishing the unidimensionality are (i) an empirical item must be significantly associated with the empirical representation of a construct, and 
(ii) it must be associated with only one construct (Chen and Paulraj, 2004). To test the unidimensionality condition, overall model fit results are investigated with all variables in the research model. An item deletion procedure is performed until the expected results on modification indices are reached, and finally these items (SP3, IT4, SOP4-5, and Lean 1-6-13-15) have been deleted from the data set to provide unidimensionality. The model fit results have been calculated as $x 2(129)=172 ; \mathrm{p}$-value $<0.007$; GFI $=$ 0.916 ; CFI $=0.970 ;$ RMSEA $=0.040$, and hence unidimensionality has been proven (Chen and Paulraj, 2004).

After the purification process, the convergent and discriminant validity was examined with the remaining items. First the exploratory factor analysis was conducted in order to test convergent validity. As can be seen in Table 5, the convergent validity was confirmed as the items were loaded to relevant factor groups with factor weights over 0.60; each four constructs' initial eigenvalues exceed the value of 1.0 (Chen and Paulraj, 2004).

Table 6

\section{Discriminant Validity Values}

\begin{tabular}{l|c|c|c|c|c}
\hline Constructs & $\begin{array}{c}\text { Cronbach's } \\
\text { Alpha† }\end{array}$ & $\mathbf{1}$ & $\mathbf{2}$ & $\mathbf{3}$ & $\mathbf{4}$ \\
\hline 1. Strategic partnership (3 items) & 0.696 & - & $.279^{* *}$ & $.243^{* *}$ & $.312^{* *}$ \\
\hline 2. Information technology (3 items) & 0.740 & $\mathbf{0 . 3 9}$ & - & $.341^{* *}$ & $.347^{* *}$ \\
\hline 3. Supplier's operational performance (3 items) & 0.759 & $\mathbf{0 . 3 3}$ & $\mathbf{0 . 4 6}$ & - & $.368^{* *}$ \\
\hline 4. Lean techniques (9 items) & 0.892 & $\mathbf{0 . 4 0}$ & $\mathbf{0 . 4 3}$ & $\mathbf{0 . 4 5}$ & - \\
\hline
\end{tabular}

Notes: $n=207$; The upper triangle shows the correlations coefficients; ${ }^{*}$ Correlation is significant at the 0.01 level (twotailed); lower triangle with bold font shows the discriminant validity test results (example demonstration calculation for the first value $[.279 /(\sqrt{ } .696 * .740)=.39])$

$\uparrow$ The Cronbach's Alpha scores for remaining items after data purification process.

To test discriminant validity, correlation coefficients between two variables were divided by the square root of the multiplication of Cronbach's alpha value for these two variables. The results of these calculations are given in Table 6. As shown in the Table 6 (lower triangle), the calculation results are lower than the threshold value (0.85) for each variable pair, thus indicating that the discriminant validity could be satisfied (Cook et al., 2011).

Common methods bias can be an issue in survey based research if both dependent and independent variables are perceptual measures (Corsten and Felde, 2005), and if responses are received from a single individual in the participant company (Singh and Power, 2009). To test for this, Harmann's one-factor-test using both exploratory and confirmatory approaches were applied. First, all items were subjected to unrotated exploratory factor analysis with the eigenvalues higher than 1.0 (Paulraj et al., 2008). The common methods bias is not a serious problem in this data set because unrotated exploratory factor analysis results are given for the four constructs which did not load in 
a single factor dimension, and explained variance is not represented by only one factor. Additionally, to test the one-factor congeneric model with confirmatory approach, all 18 items were loaded onto a single common factor construct. The indices for Harmann's one factor model were: $x 2(135)=565$, p-value $<0.001, \mathrm{GFI}=0.755, \mathrm{CFI}=0.704$ and RMSEA $=0.111$. This test result indicates that a common methods bias is unlikely to be present as the goodness-of-fit indices for this model indicate a poor fit with the data (Paulraj et al., 2008).

\section{Structural Model Tests:}

In order to test the proposed hypotheses by conducting a path analysis, SPSS-AMOS is used. For testing the first path group hypotheses, the relationships between the exogenous variables (i.e. strategic partnership, information technology and lean techniques) and endogenous variable (i.e. supplier's operational performance) are investigated. For this purpose, the remaining scale items are used to conduct the path analysis. As shown in Table 7, the results indicate that there is not statistically significant support for H1. In other words, the relationship between the strategic partnership and the supplier's operational performance is not supported based on this research data-set. Meanwhile, there is a significant relationship between the information technology and the supplier's operational performance at $\mathrm{p}<0.05$ level, and $\mathrm{H} 2$ is statistically supported. Moreover, $\mathrm{H} 3$ is strongly supported at the $\mathrm{p}<0.001$ level, showing that the lean techniques implementation is one of the important factors in operational performance.

To test whether there is any positive moderating effect of lean techniques on the relationship between the strategic partnership and the supplier's operational performance (H3a), and on the relationship between the information technology and the supplier's operational performance $(\mathrm{H} 3 \mathrm{~b})$, the metrics moderation method ${ }^{[4]}$ is used. Using metrics moderation methods with interaction terms provides the opportunity to control measurement errors and correlations between equation errors (Bortolotti et al., 2013).

Table 7

Relationships between Constructs

\begin{tabular}{|c|c|c|c|c|c|}
\hline \multirow[t]{2}{*}{ Relationships } & \multicolumn{3}{|c|}{ Unstandardized output } & \multicolumn{2}{|c|}{ Standardized output } \\
\hline & $\begin{array}{l}\text { Regression } \\
\text { Covariance }\end{array}$ & S.E. & p-value & $\begin{array}{l}\text { Regression } \\
\text { Correlation }\end{array}$ & $\mathbf{R}^{2}$ \\
\hline $\mathrm{H} 1: \mathrm{SP} \rightarrow \mathrm{SOP}$ & 0.113 & 0.069 & $0.103^{\mathrm{NS}}$ & 0.154 & 0.337 \\
\hline $\mathrm{H} 2: \mathrm{IT} \rightarrow \mathrm{SOP}$ & 0.129 & 0.060 & $0.030^{*}$ & 0.185 & \multirow{3}{*}{$\begin{array}{c}\text { (supplier's } \\
\text { operational } \\
\text { performance) }\end{array}$} \\
\hline H3: Lean $\rightarrow$ SOP & 0.200 & 0.053 & $0.000 * * *$ & 0.351 & \\
\hline H3a: SPxLean $\rightarrow$ SOP & 0.101 & 0.036 & $0.005 * *$ & 0.197 & \\
\hline H3b: ITxLean $\rightarrow$ SOP & -0.040 & 0.026 & $0.122^{\mathrm{NS}}$ & -0.106 & \\
\hline
\end{tabular}

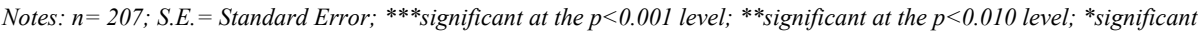
at the $p<0.050$ level; NSnot significant

${ }^{[4]}$ See, Hair et al. [2010: 181 and 756] for more detailed information about the metrics moderation method. 
To apply this method, two interaction terms ${ }^{[5]}$ were included in the model and used as moderator variables. Each interaction term is measured as a single-item variable calculated by multiplying the sum of the items making up Lean, by the sum of the items making up Information Technology, and Strategic Partnership (Frazier et al., 2004; Bortolotti et al., 2013). Therefore, the second path analysis is undertaken with the interaction terms, "SPxLean" and "ITxLean", acting to represent moderating effects in the path analysis. As reported in Table 7, the interaction term "SPxLean" had a significant association with supplier's operational performance at $\mathrm{p}<0.01$ level, indicating the moderating role. Therefore the proposed hypothesis (H3a) is statistically supported in this study. However, the lean technique applications negatively moderated the relationship between information technology and supplier's operational performance, and this relationship was not significant. For this reason, H3b could not be supported.

Finally, the squared multiple correlation coefficient associated with the endogenous construct (i.e. supplier's operational performance) was 0.337 , indicating that the constructs in the model (i.e. strategic partnership, information technology and lean techniques) accounted for thirty-four per cent of the variance in the supplier's operational performance. Therefore, these three factors have shown to play a significant role in explaining the competitive sources, -- product quality and delivery performance -- of the suppliers' operational performance as Li et al. (2006) mentioned in their study.

\section{Discussion}

Two path groups of hypotheses were empirically tested with the following conclusions: First, the impact of strategic partnership on performance was investigated. The results show that even though there is some evidence in the literature (e.g. Li et al., 2006) that strategic partnership significantly affects operational performance, based on this study no significant relationships were observed. One reason for this might be that internal factors such as lean production techniques implementation level have more effect on operational performance than external factors such as strategic supplier partnership integration. Consequentially, and given that previous research models do not contain the effect of lean production levels, this would explain the difference in findings of this study compared to the extant literature. Another possibility is that while extant literature (e.g. Li et al., 2006) uses buyer firms' evaluations, this paper has investigated the perspective of the suppliers which might be different from that of buyer firms.

Transaction collaboration through internet and sharing critical data between supply chain members are important factors in establishing close collaboration and supply chain success. Accordingly, this study has shown, 1. the positive effect of utilizing IT tools on supplier's operational performance and 2. that IT applications convey more meaning beyond communication tools for effective supply chain management. Although possessing the information technology tools is necessary to achieve operational performance, our research shows that it gives only a low level contribution (as Beta coefficient is

[5] See, Frazier et al. [2004: 120-124] for more detailed information about interaction terms. 
.18 and t-value is 3.09) to competitive competence. This low level contribution may be interpreted to mean that high level state-of-the-art technology investment does not guarantee high level competitive operational performance. Therefore, executives should not expect too much from new IT investments in terms of competitiveness, but should consider appropriate IT investments mainly for their business systems and human resources (Liker, 2004).

This research reveals that suppliers in the automotive industry should focus on implementing lean production techniques to further enhance their operational performance and their competitiveness. To improve the competitive operational performance, including increasing product quality and delivery performance, aspects of lean production like "pull system, process improvement, equipment layout, order and cleanliness of the plant" are required.

The hypothesis that lean production techniques moderate the effects of strategic partnership was supported in the path analysis. The strategic partnership relationship between the supplier and major customer does not affect the supplier's operational performance directly, although it affects operational performance when the moderating effect of the adoption of lean production techniques is present. For suppliers, establishing close partnerships with business customers is not sufficient on its own to enhance operational performance. These results can be interpreted as applications of internal lean production practices, and close supplier relations should be implemented along with it in order to maximise product quality and delivery performance (Womack et al., 1991).

Although not significant, this research also revealed a negative interaction effect of lean production techniques and information technology on supplier's operational performance. This means that the more you adopt lean practices, the less is the relative impact of IT tools on operational performance. This finding could be interpreted as the following: to use lean practices is a prerequisite factor for integrating suppliers and customers. Therefore because the knowledge transfer to increase the operational performance is already achieved by lean practices, there is no need for state-of-the-art information technology tools (Gunasekaran et al., 2008). Similarly, this argument is supported by the Toyota production philosophy mentioned in the book of Liker $(2004)^{[6]}$. According to Toyota's management philosophy, state-of-the-art technology investments should only occur when that investment proves it adds value to the production system. In Toyota's system the main role of IT tools is to provide the crucial information stream connecting related workstations. Correspondingly, Toyota never changed its basic production principles to accommodate new IT investments (Liker, 2004). Therefore, the observed situation of the Turkish automotive industry supplier firms being sceptical of the benefits of investing in new IT tools is compatible with the Toyota Production System approach.

[6] See, Liker [2004: 159-168] for more detailed information about using the reliable, thoroughly tested technology based on Toyota's management principle. 


\section{Research Implications and Limitations}

The findings of this research lead to the proposition that automotive industry oriented suppliers are practicing higher levels of lean techniques and engaging more in important partnership activities (such as participating in continuous improvement programmes, future products planning, and integrated ERP systems) than nonautomotive industry oriented suppliers. This result is consistent with the effect of the global competitive pressures on the automotive industry that forces the supply chain to become more involved in the application of lean principles. Related to this, there are obviously competitive performance differences between the suppliers depending on their early or late adoption of lean principles; it can be argued that they have an effect on the maturity of organization culture such as quality management and continuous improvement. Although there is a relatively high lean implementation level across all Turkish automotive part suppliers, there are some measures to be added for potential improvements, especially for the non-automotive oriented suppliers. For this reason it can be concluded that, in general, the implementation of lean techniques in the Turkish automotive part suppliers can be increased in the future to yield greater advantages.

This study also has investigated three important ingredients of the Toyota Production System (i.e. strategic supplier partnership, information technology and lean production techniques) using a holistic research framework. This paper makes an important contribution to validate the theoretical interaction between these aspects by using rigorous statistical tests. Even though it is known that close supplier partnership is one of the most important factors for being competitive (Li et al., 2005; Li et al., 2006), this research has shown that this effect exists only if the appropriate production system (i.e. lean production techniques implementation for automotive industry) is adopted by supplier firms.

This research shows that the three factors in the research model are important elements of operational performance. However, there are still other variables that affect the supplier's operational performance. For this reason, variables such as "information management and moving forward to production activities (i.e. postponement)" should be included in the future research model (Li et al., 2006). A further consideration is that this study has not taken into account barriers (e.g. lack of confidence, lack of collaboration intent, and so forth) to establishing effective close supplier-buyer relationships. Gotzamani and Theodorakioglou (2010) claimed in their study that these barriers are more important issues for establishing a close partnership in emerging markets than in developed countries such as Japan, the United States and Western European countries. Thus, such cultural differences might be the reason why strategic partnership has not been found to be statistically related to the operational performance in this research. Given this, future studies might consider these barriers in the research framework in order to explore their significance.

As with all empirical studies, this study embodies some limitations and also presents some new opportunities for future work. In this research the perceptual data was gathered from those in from high hierarchical ranks who are knowledgeable and authorised to respond to studies. Our approach is consistent with similar studies that also selected 
upper managerial positions as the criteria of respondents (e.g. Chen and Paulraj, 2004; Li et al., 2006). Notwithstanding this, in future studies it would be desirable to collect performance data that could be used both for evidence and to quantify the impact of lean techniques on operational performance variables. Moreover, this study uses dyadic relationships as the unit of analysis, and considers the supplier firm's perspective. There is a need to examine the relationship from the buyers' perspective. Although the complexity of data collection increases when collecting from both the buyer and their supplier, this procedure would allow researchers to validate and cross-check the information from both perspectives.

\section{Concluding Remarks}

This paper considers the effect of strategic partnership, lean production techniques and information technology tools on competitive operational performance. Examining the conjoint effect of the three factors is one of the important contributions of this paper in both theory development and future studies, and in practice including the evaluation of performance criteria.

The supplier's operational performance is considered in this research framework as a competitive source. Strategic partnership and information technology are identified as two important factors of dyadic supplier-buyer relationships. It is shown that the effect of these factors on the supplier's operational performance is dependent also on an established lean production philosophy. The relationships between the operational performance and these antecedent factors are investigated from the suppliers' point of view, and this study reveals a few critical insights for executives. Analysis of Variance (ANOVA) tests demonstrate that there is a salient difference between the lean-maturity level of automotive industry oriented suppliers and other industries related suppliers. In addition, the research findings show that lean production techniques implementation moderates the effect of strategic partnership on operational performance. Therefore, it can be concluded that suppliers should establish an effective lean production system of a similar maturity level as their target customers before attempting the strategic partnership approach. Consequentially, it can be asserted that supplier firms should strive for world-class maturity level implementations of lean production techniques to provide a foundation for maximising the advantage of strategic partnerships and thereby, following Toyota's lead ${ }^{[7]}$, increase their competitive position in the global market place.

\footnotetext{
[7] Toyota is ranked number one as the largest motor vehicle producer of the world by OICA. See, http://www.oica.net/
} wp-content/uploads//ranking-2013s-2.pdf. 


\section{References}

Akkermans, H.A., Bogerd, P., Yücesan, E., and van Wassenhove, L.N. (2003). "The Impact of ERP on Supply Chain Management: Exploratory Findings from a European Delphi Study," European Journal of Operational Research, 146(2): 284-301.

Anderson, J.C. and Gerbing, D.W. (1988). "Structural Equation Modelling in Practice: A Review and Recommended Two-Step Approach," Psychological Bulletin, 103(3): 411-423.

Arkader, R. (2001). "The Perspective of Suppliers on Lean Supply in a Developing Country Context," Integrated Manufacturing Systems, 12(2): 87-93.

Bortolotti, T., Danese, P., and Romano, P. (2013). "Assessing the Impact of Just-In-Time on Operational Performance at Varying Degrees of Repetitiveness," International Journal of Production Research, 51(4): 1117-1130.

Bruun, P. and Mefford, R.N. (2004). "Lean Production and the Internet," International Journal of Production Economics, 89(3): 247-260.

Cao, M., Vonderembse, M.A., Zhang, Q., and Ragu-Nathan, T.S. (2010). "Supply Chain Collaboration: Conceptualisation and Instrument Development," International Journal of Production Research, 48(22): 6613-6635.

Chen, I.J. and Paulraj, A. (2004). "Towards a Theory of Supply Chain Management: The Constructs and Measurements," Journal of Operations Management, 22(2): 119150.

Cook, L.S., Heiser, D.R., and Sengupta, K. (2011). "The Moderating Effect of Supply Chain Role on the Relationship Between Supply Chain Practices and Performance: An Empirical Analysis," International Journal of Physical Distribution \& Logistics Management, 41(2): 104-134.

Corsten, D. and Felde, J. (2005). "Exploring the Performance Effects of Key-Supplier Collaboration: An Empirical Investigation into Swiss Buyer-Supplier Relationships," International Journal of Physical Distribution \& Logistics Management, 35(6): 445461.

Cousins, P.D. and Menguc, B. (2006). "The Implications of Socialization and Integration in Supply Chain Management,” Journal of Operations Management, 24(5): 604-620.

Dyer, J.H. (1996). "Specialized Supplier Networks as a Source of Competitive Advantage: Evidence from the Auto Industry," Strategic Management Journal, 17(4): 271-291.

Feng, T., Li, T., Sun, L., and Wang, D. (2013). "External Involvement and Operational Performance: The Mediating Role of Internal Integration," Chinese Management Studies, 7(3): 488-507.

Frazier, P.A., Tix, A.P., and Barron, K.E. (2004). "Testing Moderator and Mediator Effects in Counseling Psychology Research," Journal of Counseling Psychology, 51(1): 115-134.

Fynes, B., Voss, C., and Burca, S. (2005). "The Impact of Supply Chain Relationship Quality on Quality Performance," International Journal of Production Economics, 96(3): 339-354.

Gotzamani, K.D. and Theodorakioglou, Y.D. (2010). "Critical Barriers to the Implementation of Close Supplier-Buyer Relationships: The Case of Greek Manufacturing Industry," International Journal of Logistics Research and Applications: A Leading Journal of Supply Chain Management, 13(3): 211-224.

Gunasekaran, A., Lai, K.H., and Cheng, T.C.E. (2008). "Responsive Supply Chain: A Competitive Strategy in a Networked Economy," OMEGA The International Journal of Management Science, 36(4): 549-564.

Gunasekaran, A. and Ngai, E.W.T. (2004). "Information Systems in Supply Chain Integration and Management," European Journal of Operational Research, 159(2): 269-295. 
Hair, J.F., Black, W.C., Babin, B.J., and Anderson, R.E. (2010), Multivariate Data Analysis (7 th $^{\text {th }}$ edition). New Jersey, USA: Pearson Prentice Hall.

Haleem, A., Sushil, Qadri, M.A., and Kumar, S. (2012). "Analysis of Critical Success Factors of World-Class Manufacturing Practices: An Application of Interpretative Structural Modelling and Interpretative Ranking Process," Production Planning \& Control, 23(10-11): 722-734.

Hicks, B.J. (2007). "Lean Information Management: Understanding and Eliminating Waste," International Journal of Information Management, 27(4): 233-249.

Hicks, B.J. and Matthews, J. (2010). “The Barriers to Realising Sustainable Process Improvement: A Root Cause Analysis of Paradigms for Manufacturing Systems Improvement," International Journal of Computer Integrated Manufacturing, 23(7): 585-602.

Hodge, G.L., Goforth-Rose, K., Joines, J.A., and Thoney, K. (2011). "Adapting Lean Manufacturing Principles to the Textile Industry," Production Planning \& Control, 22 3): 237-247.

Holweg, M. and Pil, F.K. (2008). "Theoretical Perspectives on the Coordination of Supply Chains," Journal of Operations Management, 26(3): 389-406.

Hoyt, J. and Huq, F. (2000). "From Arms-Length to Collaborative Relationships in the Supply Chain: An Evolutionary Process," International Journal of Physical Distribution and Logistics Management, 30(9): 750-764.

Hsu, C.C., Kannan, V.R., Tan, K.C., and Leong, G.K. (2008). "Information Sharing, Buyer-Supplier Relationships, and Firm Performance: A Multi-Region Analysis," International Journal of Physical Distribution \& Logistics Management, 38(4): 296310.

Jayaram, J., Vickery, S., and Droge, C. (2008). "Relationship Building, Lean Strategy and Firm Performance: An Exploratory Study in the Automotive Supplier Industry," International Journal of Production Research, 46(20): 5633-5649.

Karakadılar, I.S. and Sezen, B. (2012). "Are the Members of Auto Supply Chains Successful in Building Good Supplier-buyer Relationships? A Survey of Turkish Automotive Industry." Paper presented at the $8^{\text {th }}$ International Strategic Management Conference (ISMC), Barcelona, Spain, (June).

Koufteros, X. A., Vonderembse, M.A., and Doll, W.J. (1998). "Developing Measures of Time-Based Manufacturing," Journal of Operations Management, 16(1): 21-41.

Krafcik, J.F. (1988). “Triumph of the Lean Production System,” Sloan Management Review, Fall: 41-52.

Li, S., Rao, S.S., Ragu-Nathan, T.S., and Ragu-Nathan, B. (2005). "Development and Validation of a Measurement Instrument for Studying Supply Chain Management Practices," Journal of Operations Management, 23(6): 618-641.

Li, S., Ragu-Nathan, B., Ragu-Nathan, T.S., and Rao, S.S. (2006). "The Impact of Supply Chain Management Practices on Competitive Advantage and Organizational Performance," OMEGA The International Journal of Management Science, 34(2): 107124.

Liker, J.K. (2004), The Toyota Way: 14 Management Principles. New York, USA: McGraw Hill.

Martínez-Jurado, P.J. and Moyano-Fuentes, J. (2014). "Key Determinants of Lean Production Adoption: Evidence from the Aerospace Sector," Production Planning and Control, 25(4): 332-345.

Moyano-Fuentes, J., Sacristán-Díaz, M., and Martínez-Jurado, P.J. (2012). "Cooperation in the Supply Chain and Lean Production Adoption: Evidence from the Spanish Automotive Industry," International Journal of Operations \& Production Management, 32(9): 1075-1096.

Nahm, A.Y., Vonderembse, M.A., and Koufteros, X.A. (2004). “The Impact of Organizational Culture on Time-Based Manufacturing and Performance," Decisions Sciences, 35(4): 579-607. 
Olhager, J. and Prajogo, D. (2012). "The Impact of Manufacturing and Supply Chain Improvement Initiatives: A Survey Comparing Make-to-Order and Make-to-Stock firms," OMEGA The International Journal of Management Science, 40(2): 159-165.

Panizzolo, R., Garengo, P., Sharma, M.K., and Gore, A. (2012). "Lean Manufacturing in Developing Countries: Evidence from Indian SMEs,” Production Planning \& Control, 23(10-11): 769-788.

Paulraj, A., Lado, A.A., and Chen, I.J. (2008). "Inter-Organizational Communication as a Relational Competency: Antecedents and Performance Outcomes in Collaborative Buyer-Supplier Relationships," Journal of Operations Management, 26(1): 45-64.

Prahinski, C. and Benton, W.C. (2004). "Supplier Evaluations: Communication Strategies to Improve Supplier Performance," Journal of Operations Management, 22(1): 39-62.

Prajogo, D. and Olhager, J. (2012). "Supply Chain Integration and Performance: The Effects of LongTerm Relationships, Information Technology and Sharing, and Logistics Integration," International Journal of Production Economics, 135(1): 514522.

Riezebos, J., Warse, K., and Hicks, C. (2009). "Lean Production and Information Technology: Connection or Contradiction?" Computers in Industry, 60(4): 237-247.

Rosenzweig, E.D., Roth, A.V., and Dean Jr, J.W. (2003). "The Influence of an Integration Strategy on Competitive Capabilities and Business Performance: An Exploratory Study of Consumer Products Manufacturers," Journal of Operations Management, 21(4): 437-456.

Sakakibara, S., Flynn, B.B., and Schroeder, R.G. (1993). “A Framework and Measurement Instrument for Just-In-Time Manufacturing," Production and Operations Management, 2(3): 177-194.

Sezen, B. (2008). "Relative Effects of Design, Integration and Information Sharing on Supply Chain Performance," Supply Chain Management: An International Journal, 13(3): 233-240.

Sezen, B., Karakadılar, I.S., and Büyükozkan, G. (2012). "Proposition of a Model for Measuring Adherence to Lean Practices: Applied to Turkish Automotive Part Suppliers," International Journal of Production Research, 50(14): 3878-3894.

Shah, R. and Ward, P.T. (2007). "Defining and Developing Measures of Lean Production," Journal of Operations Management, 25(4): 785-805.

Shin, H., Collier, D.A., and Wilson, D.D. (2000). "Supply Management Orientation and SupplierBuyer Performance," Journal of Operations Management, 18(3): 317-333.

Simatupang, T.M. and Sridharan, R. (2005). "The Collaboration Index: A Measure for Supply Chain Collaboration," International Journal of Physical Distribution and Logistics Management, 35(1): 44-62.

Simpson, D.F. and Power, D.J. (2005). "Use the Supply Relationship to Develop Lean and Green Suppliers," Supply Chain Management: An International Journal, 10(1): 6068.

Singh, P.J. and Power, D. (2009). "The Nature and Effectiveness of Collaboration Between Firms, Their Customers and Suppliers: A Supply Chain Perspective," Supply Chain Management: An International Journal, 14(3): 189-200.

Spekman, R.E., Kamauff Jr. J.W., and Myhr, N. (1998). “An Empirical Investigation into Supply Chain Management: A perspective on partnerships," Supply Chain Management, 3(2): 53-67.

Stank, T., Crum, M. and Arango, M. (1999). "Benefits of Interfirm Coordination in Food Industry Supply Chains,” Journal of Business Logistics, 20(2): 21-41.

Swink, M., Narasimhan, R., and Wang, C. (2007). "Managing Beyond the Factory Walls: Effect of Four Types of Strategic Integration on Manufacturing Plant Performance," Journal of Operation Management, 25(1): 148-164. 
Theodorakioglou, Y., Gotzamani, K., and Tsiolvas, G. (2006). "Supplier Management and its Relationship to Buyers' Quality Management," Supply Chain Management: An International Journal, 11(2): 148-159.

Villena, V.H., Gomez-Mejia, L.R., and Revilla, E. (2009). "The Decision of the Supply Chain Executive to Support or Impede Supply Chain Integration: A Multidisciplinary Behavioral Agency Perspective," Decision Sciences, 40(4): 635-665.

Ward, P. and Zhou, H. (2006). "Impact of Information Technology Integration and Lean/Just-In-Time Practices on Lead-Time Performance," Decision Sciences, 37(2): 177-203.

Wiengarten, F., Humphreys, P., Cao, G., Fynes, B., and McKittrick, A. (2010). “Collaborative Supply Chain Practices and Performance: Exploring the Key Role of Information Quality," Supply Chain Management: An International Journal, 15(6): 463-473.

Womack, J.P., Jones, D.T., and Roos, D. (1991). The Machine That Change The World: The Story of Lean Production, New York, USA: Harper-Prennial. 


\section{Appendix}

\section{Constructs and Associated Items}

\begin{tabular}{r|r|l}
\hline Constructs & $\begin{array}{r}\text { Item } \\
\text { label }\end{array}$ & Description \\
\hline Strategic Partnership: (1= Definitely disagree, 4= Neither agree nor disagree, 7= Definitely agree) \\
\hline SP1 & ${ }^{a}$ We intend to maintain a long-term relation with our customer. \\
\hline SP2 & $\begin{array}{l}\text { aWe are actively participating in the continuous improvement program of our } \\
\text { customer. }\end{array}$ \\
\hline SP3 & $\begin{array}{l}\text { an making future plans our customer attaches importance to our views and } \\
\text { suggestions. }\end{array}$ \\
\hline SP4 & $\begin{array}{l}\text { Our customer contacts us in advance about the changes we will make on its } \\
\text { products. }\end{array}$ \\
\hline SP5 & Our customer sees us as a problem solving partner. \\
\hline SP6 & Our customer intends to continue its business relation with us.
\end{tabular}

Information Technology: (1= Definitely disagree, $4=$ Neither agree nor disagree, $7=$ Definitely agree $)$

\begin{tabular}{|c|c|}
\hline IT1 & $\begin{array}{l}\text { Our customer is submitting its orders via an Enterprise Resource Planning } \\
\text { program (such as SAP, ORACLE etc) integrated to its suppliers. }\end{array}$ \\
\hline IT2 & $\begin{array}{l}\text { In communicating with our customer, we are using cutting-edge communication } \\
\text { technologies (teleconference, internet etc). }\end{array}$ \\
\hline IT3 & $\begin{array}{l}\text { In communicating with us and maintaining the information flow, our customer } \\
\text { uses information technologies. }\end{array}$ \\
\hline IT4 & $\begin{array}{l}\text { aWe are using rapid communication technologies in responding to the demands and } \\
\text { complaints of the customer. }\end{array}$ \\
\hline IT5 & $\begin{array}{l}\text { aWhen necessary, we can provide immediate stock information to the customer via } \\
\text { the internet. }\end{array}$ \\
\hline \multicolumn{2}{|c|}{ Supplier's Operational Performance: $(1=$ Very poor, $4=$ Neither poor nor well, $7=$ Very well $)$} \\
\hline SOP1 & Product quality \\
\hline SOP2 & Delivery term \\
\hline SOP3 & Delivery reliability \\
\hline SOP4 & ${ }^{\text {aResponsiveness to demanded changes }}$ \\
\hline SOP5 & ${ }^{\mathrm{a}}$ Overall performance \\
\hline \multicolumn{2}{|c|}{ Lean Techniques: $(1=$ Not practiced at all, $4=$ Partially practiced, $7=$ Fully practiced $)$} \\
\hline Lean01 & ${ }^{a}$ We spend effort to reduce "set-up time" of machinery and equipment. \\
\hline Lean02 & Pull system and KANBAN is used in our production facility. \\
\hline Lean03 & ${ }^{a}$ We spend effort to reduce production lot sizes. \\
\hline Lean04 & ${ }^{a}$ We avoid holding more than necessary work in process inventories. \\
\hline Lean05 & Wherever possible, one piece flow is applied. \\
\hline Lean06 & 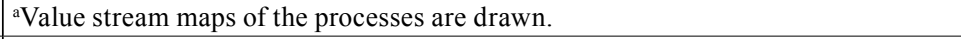 \\
\hline Lean07 & We spend effort to improve the stream of processes. \\
\hline Lean 08 & $\begin{array}{l}\text { Preventive maintenance work is routinely carried out with the support of all } \\
\text { employees. }\end{array}$ \\
\hline Lean09 & Processes can be followed easily with the application of 5S. \\
\hline Lean10 & Working areas are regularly cleaned and visual order is enhanced. \\
\hline Lean11 & $\begin{array}{l}\text { "Fishbone Diagram", "Quality Circle" and similar techniques are employed to find } \\
\text { out the root causes of problems. }\end{array}$ \\
\hline Lean12 & A successful suggestions system is applied in our company. \\
\hline Lean13 & aContinuous improvement culture is established in our company. \\
\hline Lean14 & Error proof (POKA YOKE) ideas are generated in our company. \\
\hline Lean 15 & 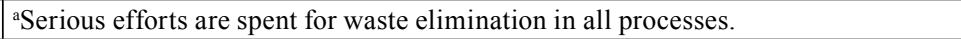 \\
\hline
\end{tabular}

Note: altems were dropped according to data purification process. 